\title{
Winged ants (Hymenoptera: Formicidae) presence in twigs on the leaf litter of Atlantic Forest
}

\author{
Tae Tanaami Fernandes ${ }^{1}{ }^{\circledR}$, Rogério R. Silva $^{2}$, Débora Rodrigues de Souza-Campana ${ }^{2}$, \\ Otávio Guilherme Morais da Silva² \& Maria Santina de Castro Morini ${ }^{\text {* }}$ \\ ${ }^{1}$ Universidade de Mogi das Cruzes, Laboratório de Mirmecologia do Alto Tietê, Rua Dr. Cândido Xavier de \\ Almeida e Souza, 200, CEP 08780-911, Mogi das Cruzes, SP, Brasil \\ ${ }^{2}$ Museu Paraense Emílio Goeldi, Coordenação de Ciências da Terra e Ecologia, Avenida Perimetral, 1901, \\ Terra Firme, CEP 66077-830, Belém, PA, Brasil \\ *Corresponding author: Maria Santina de Castro Morini, e-mail: mscmorini@gmail.com
}

FERNANDES, T. T., SILVA, R. R., SOUZA-CAMPANA, D. R., SILVA, O. G. M., MORINI, M. S. C. Winged ants (Hymenoptera: Formicidae) presence in twigs on the leaf litter of Atlantic Forest. Biota Neotropica 19(3): e20180694. http://dx.doi.org/10.1590/1676-0611-BN-2018-0694

\begin{abstract}
In the leaf litter, ants have various nesting resources available, such as live or dead trunks, twigs, leaves, fruits and seeds. On the twigs, there are adults and immature individuals, but also the queen and winged. The production of wings requires time and energy from the colony. The objective of this study was to investigate the presence of winged in ant colonies in twigs on the leaf litter. Our prediction is that the richness and abundance of winged in twigs are the greatest in rainy months. We collected all twigs with ants in 552 plots with $16 \mathrm{~m}^{2}$, totaling $8,832 \mathrm{~m}^{2}$ of leaf litter, in areas located in the Brazilian Atlantic Domain. We compared the species richness and the number of colonies with and without winged, as well as the number of winged over a year. In total, we collected 1,521 twigs with colonies belonging to 92 species of ants. The rate of twigs with winged was low, about $12 \%$. In colonies with winged, the total number of twigs, species and amount of winged does not differ between the months considered dry and rainy. The majority of winged species are leaf litter dwellers, such as Linepithema neotropicum, recorded with the highest amount of winged irrespective of the period. Arboreal species colonized $15 \%$ of the twigs and, in $1 / 3$ of these species, winged were recorded as part of the composition of the colony. Although winged represent a small percentage of the colony in twigs, our results indicate that this feature is important for the life cycle of $44 \%$ of the species that occupy twigs, considering that winged are fundamental for the dispersion of the colony. Keywords: Dead wood, mating, satellite nest, inhabitant of leaf litter, arboreal habitat.
\end{abstract}

\section{Colônias de formigas (Hymenoptera: Formicidae) com alados em galhos na serapilheira de Floresta Atlântica}

Resumo: Na serapilheira as formigas têm disponíveis diversos recursos de nidificação, como troncos e galhos vivos ou mortos, folhas, frutos e sementes. Nos galhos são encontrados indivíduos adultos e imaturos, mas também rainha e alados. A produção de alados exige tempo e energia por parte da colônia. O objetivo deste estudo foi investigar a presença de alados em colônias de formigas em galhos na serapilheira. Nossa hipótese é que a riqueza e abundância de alados em galhos são maiores nos meses chuvosos. Nós coletamos todos os galhos com formigas em 552 parcelas de $16 \mathrm{~m}^{2}$, totalizando $8.832 \mathrm{~m}^{2}$ de serapilheira em áreas localizadas no Domínio Atlântico brasileiro. Comparamos a riqueza de espécies e o número de galhos com e sem alados, bem como o número de alados ao longo de um ano. No total coletamos 1.521 galhos com colônias, pertencentes a 92 espécies de formigas; a taxa de galhos com alados foi baixa, cerca de $12 \%$. Nas colônias com alados, o número total de galhos, espécies e quantidade de alados não diferem entre os meses secos ou chuvosos. A maioria das espécies com alados é habitante da serapilheira, como Linepithema neotropicum, registrada com a maior quantidade de alados, independente do período. Espécies arborícolas colonizaram 15\% dos galhos e, em 1/3 dessas espécies, alados foram registrados fazendo parte da composição da colônia. Apesar de os alados representarem uma pequena porcentagem da colônia em galhos, nossos resultados indicam que este recurso é importante para o ciclo de vida de 50\% das espécies que os ocupam, considerando que alados são fundamentais para a dispersão da colônia.

Palavras-chave: Madeira morta, acasalamento, ninho satélite, habitantes de serapilheira, habitat arbóreo. 


\section{Introduction}

The first cycle of life of an ant colony is complete when there is release of winged, which allows species dispersal (Hölldobler \& Wilson 1990). The production of winged requires time and a high energy investment by the colony (Frank 1987). Temperature and rainfall are important stimuli for winged production (Frederickson 2006, Nielsen et al. 2016) and for the synchronized release of different colonies of the same species (Kaspari et al. 2001a, Peeters \& Molet 2010).

Rainfall, in addition to influencing winged release (Kaspari et al. 2001b), facilitates soil excavation for nesting after mating (Hölldobler \& Wilson 1990). Mating is the beginning of breeding (Nene et al. 2016), and is important for understanding population ecology and species distribution (Dunn et al. 2007, Noordijk et al. 2008). For example, the species Oecophylla smaragdina (Fabricius 1775) has a long mating period, and the colony hosts winged at different stages of development that are released gradually (Nielsen et al. 2016).

The foundation of colonies by ants happens from the soil to the highest extracts of the vegetation, such as the canopies of forests. Sites with diverse nesting resources, such as the leaf litter of tropical forests, also containing live or dead trunks and twigs, leaves, fruits and seeds, are the most densely colonized (Hölldobler \& Wilson 1990, Delabie et al. 2000). Twigs from tree fragmentation are one of the most commonly used resources in the litter by ant colonies (Gomes et al. 2013), and where we may find between 35-70 species of ants (Carvalho \& Vasconcelos 2002, Souza-Campana et al. 2017). In spite of the low durability of the twigs, causing displacement of the colonies (Byrne 1994), winged have been recorded frequently (Fernandes et al. 2012, Souza et al. 2012).

In this work, we investigate the presence of winged in colonies that occupy twigs as nesting sites in the leaf litter of the Brazilian Atlantic Forest. We compare the number of species that produce winged and the number of winged over a year. As the warm and rainy season in the Atlantic Forest are known to be the period of higher ant activity (Nene et al. 2016) and with more favorable environmental conditions for the release of the breeding stock (Santos \& Del-Claro 2009), we expect to find such an influence also in species that occupy twigs.

\section{Material and Methods}

\section{Study area, collection and identification of ants}

The collection expeditions were carried out in 43 fragments of vegetation at different conservation levels belonging to nine municipalities in the Brazilian Atlantic Domain (Fig. 1). The altitudes are between 600 and $850 \mathrm{~m}$. According to the Köppen classification, the climate of the region is mesothermic with a dry winter (Cwb), with an annual rainfall accumulation of 1,500 $\mathrm{mm}$ (Cptec-Inpe 2018). In these municipalities, the rainy season occurs between March and October, and the dry season occurs between April and September (Cptec-Inpe 2018).

The collections were carried out along a linear transect between 2010 and 2015 covering the months considered as dry (April to September) and rainy (October to March) for the region. In each site, we determined $4 \times 4 \mathrm{~m}$ plots. The distance between plots was 10-50 $\mathrm{m}$, and the number of plots (6-30) was determined in function of the size of the study areas. All twigs (= nests) with ants were collected (range diameter: 2.85 to $123.77 \mathrm{~mm}$ ) and packed in plastic bags individually, and taken to the laboratory for colony analysis; 552 plots were analyzed, totaling $8,832 \mathrm{~m}^{2}$ of litter. In the laboratory, we opened the twigs in search for ant colonies. We classified twigs as occupied if they contained $\geq 10$ workers; if fewer than 10 workers were present, twigs were considered occupied if they contained immatures, queens, or winged males (Fernandes et al. 2012).

For each twig, the number of individuals was counted. For identification of species/morphospecies, we used the catalog by Suguituru et al. (2015) and a comparison with the specimens deposited in the reference collection of Formicidae of the Upper Tietê Basin. The winged were identified based on the identification of worker ants. We deposited all the vouchers at the Laboratory of Mirmecology of the University of Mogi das Cruzes.

\section{Data analysis}

The total number of ant species and twigs with winged or wingless, and the number of winged on twigs were compared between the one-year dry and rainy periods using Mann-Whitney test. The significance level adopted was $5 \%$, and the tests were performed using the software BioEstat 5.0 (Ayres et al. 2007).

\section{Results}

In 1,521 twigs we found 89 species of ants (Table 1), most of them inhabiting leaf litter. The arboreal ants represent 27 species of the total, 12 of which are truly arboreal (genera Cephalotes, Myrmelachista, Procryptocerus and Pseudomyrmex) and 15 possibly arboreal (genera Camponotus and Crematogaster). From this total of twigs, arboreal ants colonized 235 of them (15.45\%) (Table 1).

Few twigs $(186=12 \%)$ have colonies with winged, but with 39 (44\%) species of ants. Of these, 12 are vegetation species, among which six were defined as arboreal (three species of Myrmelachista, two of Procryptocerus and one of Pseudomyrmex) and six were classified as possibly arboreal (five species of Camponotus and one of Crematogaster). The other species are leaf litter inhabitants (Table 1).

The total number of twigs with wingless and winged, the total number of wingless and winged ant species, and the abundance of winged do not differ between both periods of the year (Table 2). Winged in twigs were more frequent between October and January (Fig. 2).

The species with the highest occurrence and abundance are not the same when we analyze descriptively the driest and rainiest months (Fig 3). Winged ants of Brachymyrmex admotus Mayr 1887 are more frequent when there is more rain, while Gnamptogenys striatula Mayr 1884 occur in the driest months. Nylanderia sp. 1 and G. striatula only showed winged ants in twigs in the driest months (Fig. 3A). Regardless of the period of the year, Linepithema neotropicum Wild 2007 is the species with the highest number of winged (Fig. 3B).

\section{Discussion}

Our results indicate that the number of colonies with winged is low throughout the year, but the presence of breeders is constant for about half of the species that occupy the twigs. We found that most species occupying twigs also inhabit the litter. Few species are totally arboreal. 


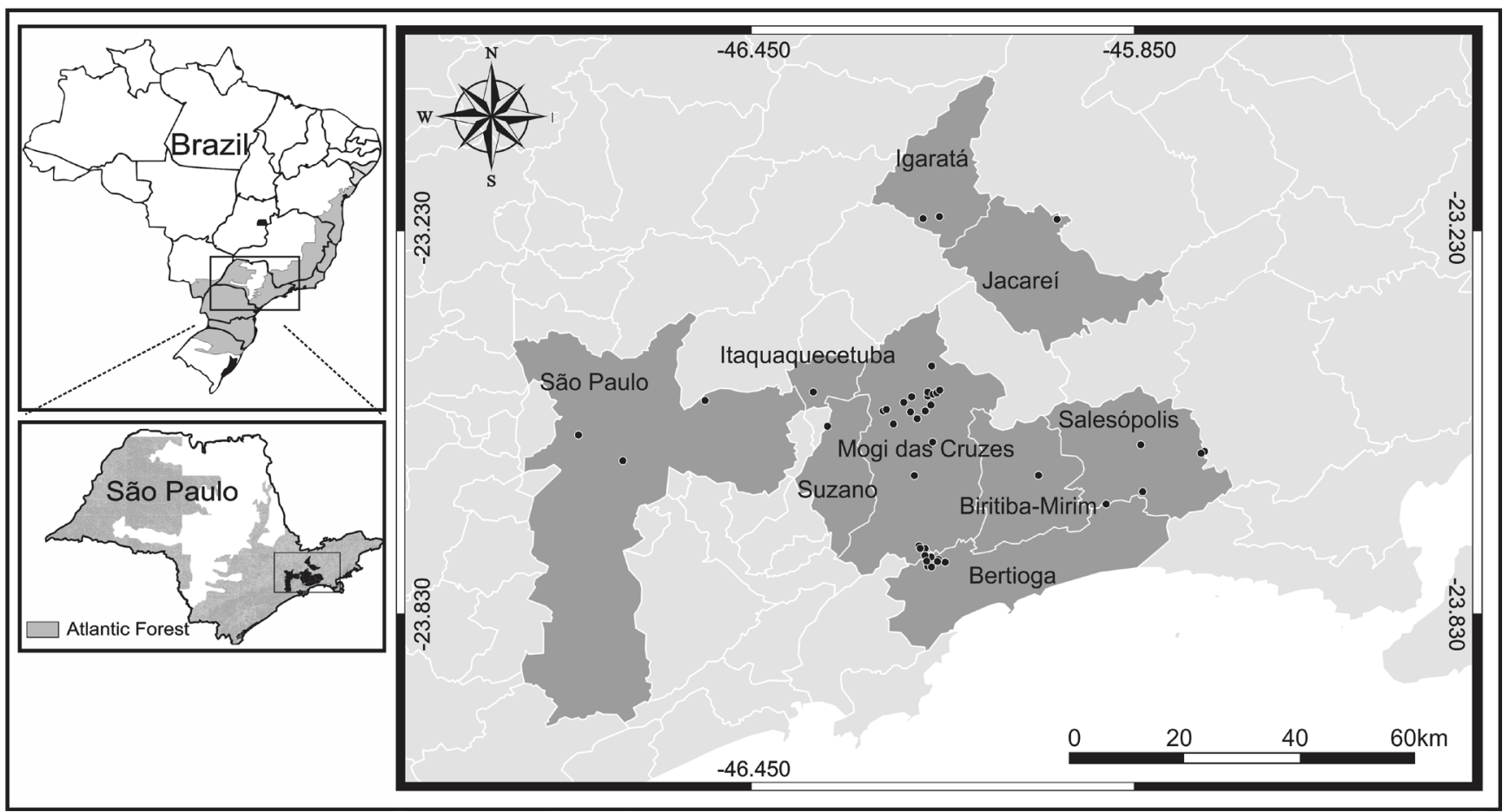

Figure 1. Location of ant collection areas in twigs in the leaf litter in municipalities within the Brazilian Atlantic Domain.

Table 1. List of ant species in twigs on the leaf litter of the Atlantic Forest. The columns describe the number of twigs with and without the presence of winged in two periods of the year.

\begin{tabular}{|c|c|c|c|c|}
\hline \multirow{2}{*}{ Species/morphospecies } & \multicolumn{2}{|c|}{ Dry period } & \multicolumn{2}{|c|}{ Rainy period } \\
\hline & Wingless & Winged & Wingless & Winged \\
\hline Acanthognathus ocellatus Mayr, 1887 & 3 & - & 3 & 1 \\
\hline Acanthognathus rudis Brown \& Kempf, 1969 & 6 & 1 & 5 & 3 \\
\hline Anochetus altisquamis Mayr, 1887 & - & - & 1 & - \\
\hline Brachymyrmex admotus Mayr, 1887 & 112 & 3 & 21 & 29 \\
\hline Brachymyrmex heeri Forel, 1874 & 5 & - & 1 & - \\
\hline Camponotus alboannulatus Mayr, 1887 & 11 & 1 & 17 & 3 \\
\hline Camponotus blandus (Smith, 1858) & - & - & 3 & 1 \\
\hline Camponotus crassus Mayr, 1862 & 5 & 4 & - & - \\
\hline Camponotus hedwigae Forel, 1912 & 2 & - & 2 & - \\
\hline Camponotus novogranadensis Mayr, 1870 & 3 & - & 1 & - \\
\hline Camponotus sp.5 & 9 & 1 & 5 & 1 \\
\hline Camponotus sp.18 & - & - & 1 & - \\
\hline Camponotus sp.20 & 1 & 1 & - & - \\
\hline Cardiocondyla wroughtonii (Forel, 1890) & 1 & - & - & - \\
\hline Cephalotes pusillus (Klug, 1824) & 2 & - & - & - \\
\hline Crematogaster curvispinosa Mayr, 1862 & 7 & - & 2 & - \\
\hline Crematogaster rochai Forel, 1903 & 3 & - & - & - \\
\hline Crematogaster sp.1 & 3 & - & 7 & 2 \\
\hline Crematogaster sp.7 & 4 & - & - & - \\
\hline Crematogaster sp. 18 & 8 & - & 4 & - \\
\hline Crematogaster sp.19 & 1 & - & - & - \\
\hline Crematogaster sp. 20 & - & - & 2 & - \\
\hline Cyphomyrmex rimosus (Spinola, 1851) & 1 & 1 & - & 1 \\
\hline
\end{tabular}


Fernandes, T.T. et al.

Continuation Table 1.

\begin{tabular}{|c|c|c|c|c|}
\hline \multirow{2}{*}{ Species/morphospecies } & \multicolumn{2}{|c|}{ Dry period } & \multicolumn{2}{|c|}{ Rainy period } \\
\hline & Wingless & Winged & Wingless & Winged \\
\hline Gnamptogenys striatula Mayr, 1884 & 13 & 9 & 24 & - \\
\hline Heteroponera dolo (Roger, 1860) & 1 & - & 2 & - \\
\hline Heteroponera mayri Kempf, 1962 & - & - & 16 & 2 \\
\hline Hypoponera sp.7 & - & - & 7 & - \\
\hline Hypoponera sp.10 & - & - & 5 & 1 \\
\hline Hypoponera sp.11 & - & - & 12 & 3 \\
\hline Hypoponera sp.12 & 7 & 1 & 19 & 5 \\
\hline Megalomyrmex goeldii Forel, 1912 & 4 & - & - & - \\
\hline Megalomyrmex iheringi Forel, 1911 & 1 & - & 1 & - \\
\hline Megalomyrmex sp.n. & 1 & - & - & - \\
\hline Mycetarotes parallelus (Emery, 1906) & - & - & 1 & - \\
\hline Myrmelachista catharinae Mayr, 1887 & 3 & - & 18 & 4 \\
\hline Myrmelachista nodigera Mayr, 1887 & 2 & - & 1 & - \\
\hline Myrmelachista reticulata Borgmeier, 1928 & - & 1 & - & - \\
\hline Myrmelachista ruzskyi Forel, 1903 & 13 & - & 4 & 3 \\
\hline Neoponera crenata (Roger, 1861) & 2 & - & 5 & 3 \\
\hline Pheidole sarcina Forel, 1912 & 68 & 1 & 107 & 10 \\
\hline Pheidole sigillata Wilson, 2003 & 87 & 7 & 34 & 1 \\
\hline Pheidole sospes Forel, 1908 & 40 & 6 & 48 & 10 \\
\hline Pheidole triconstricta Forel, 1886 & 1 & - & - & - \\
\hline Pheidole gr. tristis sp. & 2 & - & 18 & 4 \\
\hline Pheidole sp.18 & 2 & - & - & - \\
\hline Pheidole sp.19 & - & - & 5 & 1 \\
\hline Pheidole sp.23 & - & - & 3 & - \\
\hline Pheidole sp.37 & 3 & - & - & - \\
\hline Pheidole sp.39 & 1 & - & - & 1 \\
\hline Pheidole sp.43 & 1 & - & 30 & - \\
\hline Pheidole sp.44 & 9 & - & - & - \\
\hline Pheidole sp.51 & - & - & 4 & 3 \\
\hline Pheidole sp.52 & 2 & - & 3 & - \\
\hline Pheidole sp.53 & - & - & 1 & - \\
\hline Prionopelta punctulata Mayr, 1866 & - & - & 2 & - \\
\hline Procryptocerus adlerzi (Mayr, 1887) & 5 & 1 & 6 & - \\
\hline
\end{tabular}


Continuation Table 1.

\begin{tabular}{|c|c|c|c|c|}
\hline \multirow{2}{*}{ Species/morphospecies } & \multicolumn{2}{|c|}{ Dry period } & \multicolumn{2}{|c|}{ Rainy period } \\
\hline & Wingless & Winged & Wingless & Winged \\
\hline Procryptocerus sp. 2 & 3 & - & 4 & 2 \\
\hline Pseudomyrmex gracilis (Fabricius, 1804) & 5 & - & - & - \\
\hline Pseudomyrmex phyllophilus (Smith, 1858) & 18 & 2 & 8 & 1 \\
\hline Pseudomyrmex gr. pallidus sp. & 2 & - & 6 & - \\
\hline Solenopsis saevissima (Smith, 1855) & 1 & - & - & - \\
\hline Solenopsis sp.2 & 46 & 1 & 40 & 8 \\
\hline Solenopsis sp.3 & 7 & 3 & 4 & - \\
\hline Solenopsis sp.4 & - & - & 5 & - \\
\hline Strumigenys crassicornis Mayr, 1887 & 3 & - & 1 & - \\
\hline Strumigenys sp.n & 1 & - & - & - \\
\hline Wasmannia affinis Santschi, 1929 & 7 & - & 8 & 3 \\
\hline Wasmannia auropunctata (Roger, 1863) & 19 & - & - & - \\
\hline Wasmannia sigmoidea (Mayr, 1884) & 12 & - & - & - \\
\hline
\end{tabular}

Table 2. Comparison of species richness, number of twigs and number of winged in twigs with presence or absence of winged in two periods of the year in areas of Atlantic Forest. Median (amplitude) of total twigs, species richness and total number of winged.

\begin{tabular}{|c|c|c|c|c|c|c|c|}
\hline \multirow{2}{*}{ Colony } & & \multicolumn{2}{|c|}{ Dry period } & \multicolumn{2}{|c|}{ Rainy period } & \multirow{2}{*}{ Test } & \multirow{2}{*}{$p$} \\
\hline & & Total & Median (amplitude) & Total & Median (amplitude) & & \\
\hline & Species & 66 & $17(3-20)$ & 62 & $8(4-18)$ & $\mathrm{U}=0.6405$ & 0.5218 \\
\hline & Species & 23 & $3.5(2-16)$ & 34 & $9(5-12)$ & $\mathrm{U}=1.7614$ & 0.0782 \\
\hline & $\begin{array}{c}\text { Abundance of } \\
\text { winged ants }\end{array}$ & 750 & $136(8-240)$ & 1,249 & $217(31-374)$ & $\mathrm{U}=1.1209$ & 0.2623 \\
\hline
\end{tabular}

In addition, we did not detect the influence of dry or rainy months on the presence of winged in twigs, although the release of winged is related to the wetter season since rain is considered an important stimulus (Torres et al. 2001, Santos \& Del-Claro 2009).

The production of winged is influenced by factors such as size (Frederickson 2006) and availability (Fiala et al. 2017) of the resource occupied by ants. For some species, such as C. castaneus (Latreille, 1802), the production of winged is seasonal (Nascimento et al. 2001, Dunn et al. 2007). However, for others, such as Azteca instabilis (Smith, 1862), the production of winged occurs independently from the season (Kaspari et al. 2001b), resembling what we detected in this study. The fact that there is no characteristic period for winged production may indicate a strategy to avoid competition for colonization sites. Arboreal species such as C. captiosa (Forel, 1911) use this strategy and produce winged throughout the year (Fiala et al. 2017). This suggests that $32 \%$ of the species of our work, which are associated with arboreal habitat and were recorded with winged, may also adopt this type of reproductive behavior.

The twig is a resource of low durability (Byrne 1994), which does not match the time for production of winged individuals, which requires colony maturity (Hölldobler \& Wilson 1990). Thus, when it comes to arboreal species, the twig of the tree may contain winged that, when falling in the leaf litter, release the breeders. In this case, the stay on the twig should be only for maturing and dispersal of winged. Nakano et al. (2012) discuss this possibility for species of Myrmelachista, which is an exclusively arboreal genus. In the production and dispersion of breeders there is great energy expenditure (Frank 1987) and the arboreal environment is poor in certain components (example: nitrogen) (Wilson 


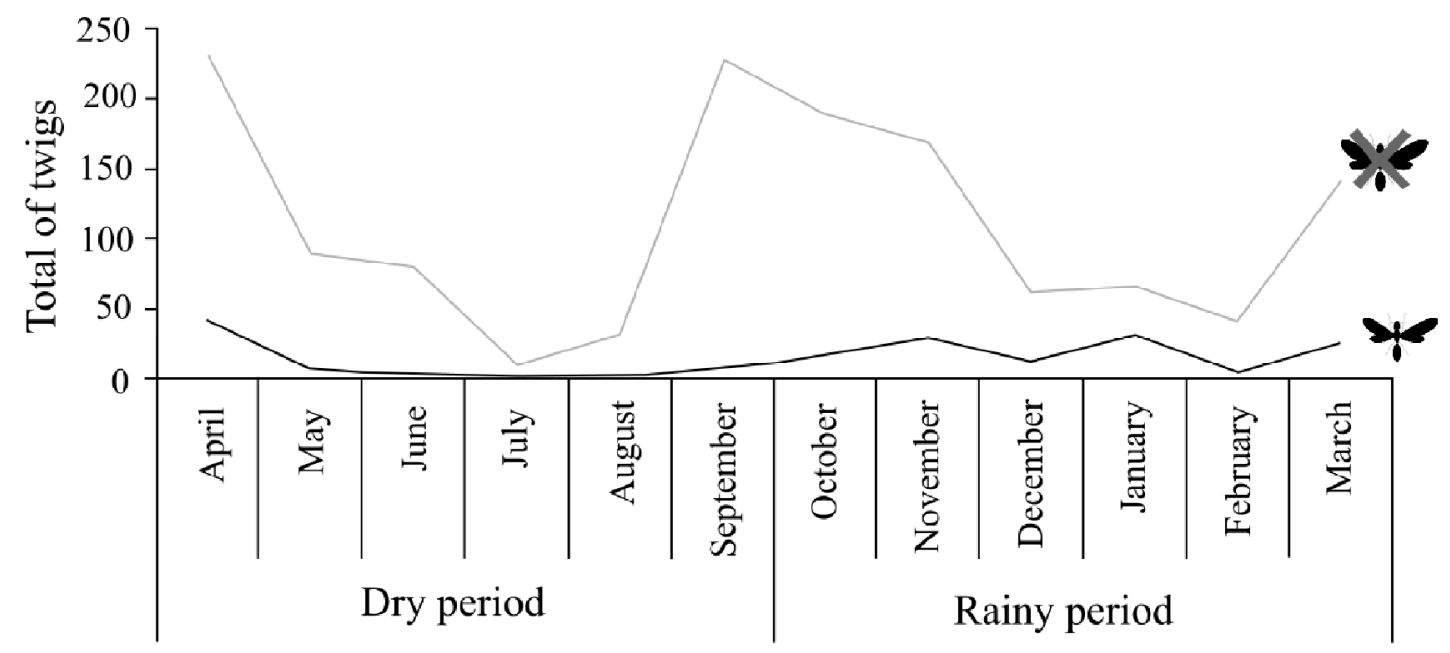

Figure 2. Number of twigs with colonies of ants with and without wings in the leaf litter of Atlantic Forest throughout the year.

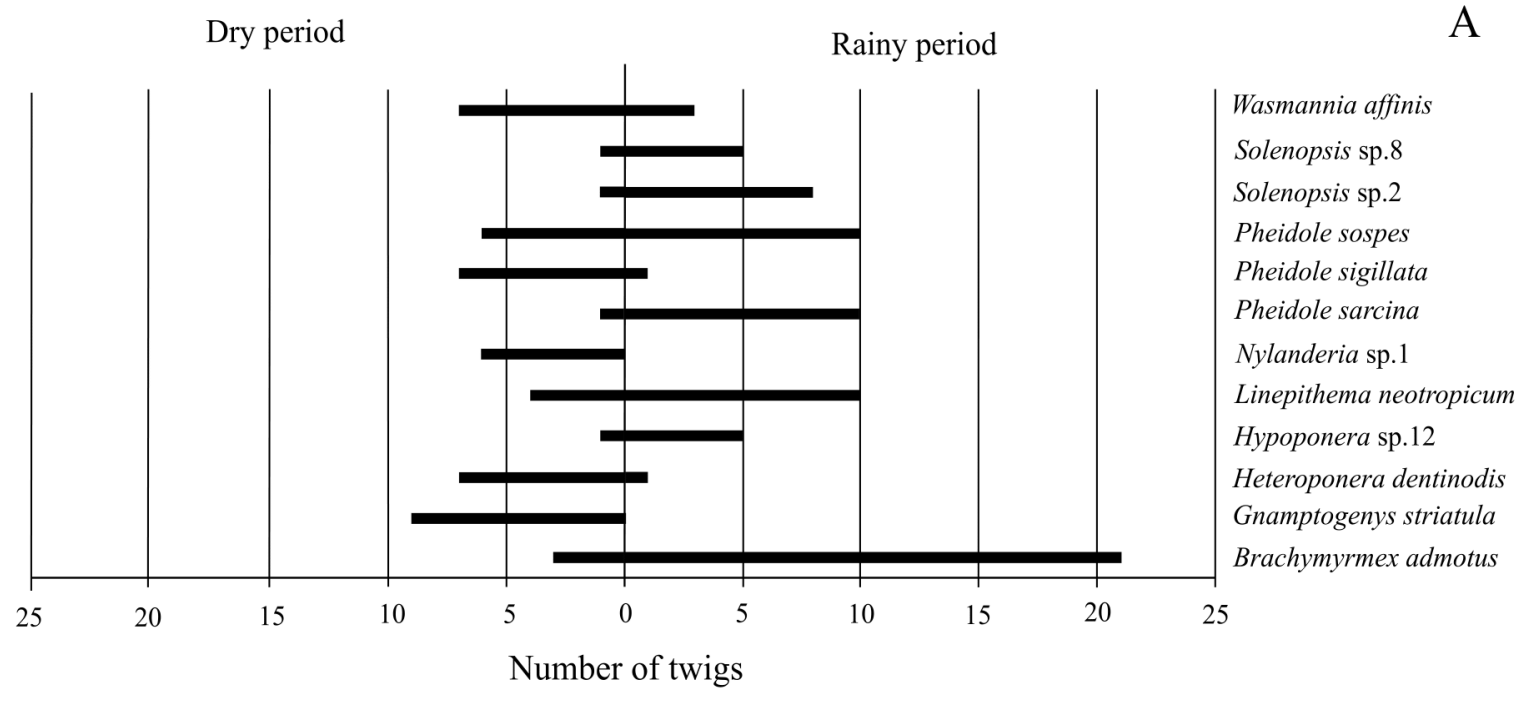

Dry period

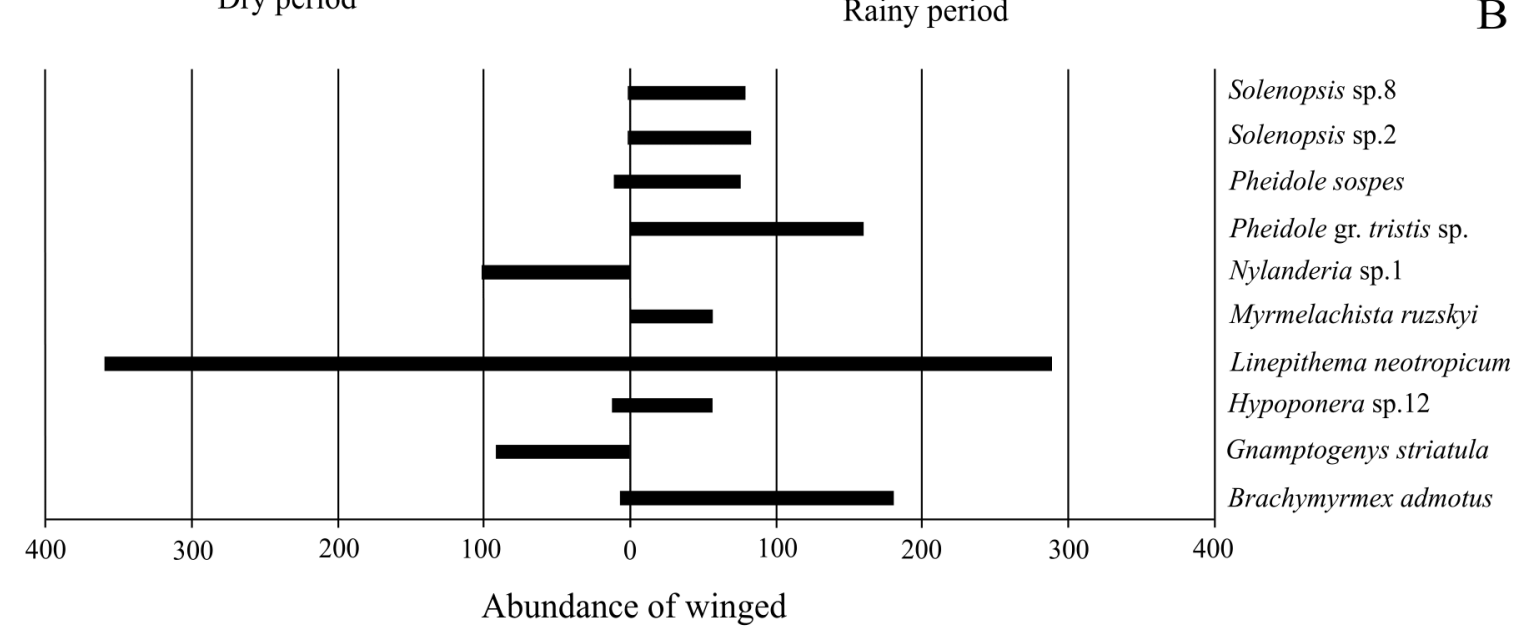

Figure 3. Species of ants in a greater number of twigs with winged ants (A) and with greater abundance of winged ants (B) according to dry and rainy periods. 
\& Hölldobler 2005) and drier when compared to the leaf litter (Davidson \& Patrell-Kim 1996, Yanoviak \& Kaspari 2000). In this case, we suggest that some arboreal species are using biotic and abiotic conditions provided by the leaf litter. The ecological success of arboreal ants is a reflection of the adaptation of species to the arboreal environment (Yanoviak \& Kaspari 2000), but also, possibly, because they are able to use the resources in the leaf litter during the maturing and dispersal phase of winged ants. However, for most species that colonize twig, the permanence should be comparatively longer, allowing not only the dispersion, but also the production of breeders.

Ants inhabit of the leaf litter that occupy twig produce winged continuously throughout the year, indicating that the resource is important to the life cycle of litter dwellers and, especially, to arboreal species. In view of the continuous presence of winged on a resource that is classified as ephemeral, we suggest that further studies be carried out studying the biology of species that occupy twigs on the leaf litter. This will allow the conservation of the diversity of this fauna on the leaf litter.

\section{Acknowledgements}

We would like to thank the financial support from FAPESP (grant $\mathrm{N}^{\mathrm{o}}$ 2013/16861-5), FAEP/UMC, SIS Bio (authorization No 45492), Coordenação de Aperfeiçoamento de Pessoal de Nível Superior (CAPES) for fellowship to the first author and L. Menino for preparing the map.

\section{Author Contributions}

Tae Tanaami Fernandes: Contribution to data collection; contribution to data analysis and interpretation; contribution to manuscript preparation; contribution to critical revision, adding intelectual content.

Rogério R. Silva: Contribution to data analysis and interpretation; contribution to manuscript preparation; contribution to critical revision, adding intelectual content.

Débora Rodrigues de Souza-Campana: Substantial contribution in the concept and design of the study, contribution to data analysis and interpretation; contribution to manuscript preparation.

Otávio Guilherme Morais da Silva: contribution to data collection, contribution to data analysis and interpretation, contribution to manuscript preparation.

Maria Santina de Castro Morini: Substantial contribution in the concept and design of the study; contribution to manuscript preparation; contribution to critical revision, adding intelectual content.

\section{Conflicts of interest}

The authors declare that they have no conflict of interest related to the publication of this manuscript.

\section{Availability of data and material}

The datasets used and/or analyzed during the current study are available from the corresponding author on reasonable request.

\section{References}

AYRES, M., AYRES, M.J., AYRES, D.L. \& SANTOS, A.S. 2007. BioEstat 5.0: aplicações estatísticas nas áreas das ciências biológicas e médicas. Instituto de Desenvolvimento Sustentável Mamirauá, Belém.

BYRNE, M.M. 1994. Ecology of twig-dwelling ants in a wet low land tropical forest. Biotropica. 26: 61-72.

CARVALHO, K.S. \& VASCONCELOS, H.L. 2002. Comunidade de formigas que nidificam em pequenos galhos da serrapilheira em floresta da Amazônia central, Brasil. Rev. Bras. Entomol. 46: 115-121.

CPTEC-INPE. http://clima.cptec.inpe.br. (Last access in: 04/04/2018).

DAVIDSON, D.W. \& PATRELL-KIM, L.J. 1996. Tropical arboreal ants: Why so abundant? In Neotropical biodiversity and conservation (A. Gibson, ed.). UCLA Herbarium Publ., Los Angeles, p.127-140.

DELABIE, J.H.C, AGOSTI, D. \& NASCIMENTO, I.C. 2000. Litter ant communities of the brazilian atlantic rain forest region. In Sampling grounddwelling ants: case studies from the word's rain forests (D. Agosti, J. Majer, L. Alonso, T. Schultz, ed.). School of environmental biology, Bulletin n ${ }^{\circ} 18$, Australia, p.1-17.

DUNN, R.R., PARKER, C., GERAGHTY, M. \& SANDERS, N.J. 2007. Reproductive phenologies in a diverse temperate ant fauna. Ecol. Entomol. 32: $135-142$.

FERNANDES, T.T., SILVA, R.R., SOUZA, D.R., ARAÚJO, N. \& MORINI, M.S.C. 2012. Undecomposed twigs in the leaf litter as nest-building resources for ants (Hymenoptera: Formicidae) in areas of the atlantic forest in the southeastern region of Brazil. Psyche J. Entomol. 2012: 1-8.

FIALA, B., HASHIM, R.B., DUMPERT, K. \& MASCHWITZ, U. 2017. Nuptial flight of the southeast asian plant-ant Crematogaster captiosa (Forel, 1911) and the phenology of colony founding. Asian Myrmecol. 9: 1-14.

FRANK, S.A. 1987. Variable sex ratio among colonies of ants. Behav. Ecol. Sociobiol. 20: 195-201.

FREDERICKSON, M.E. 2006. The reproductive phenology of an amazonian ant species reflects the seasonal availability of its nest sites. Oecologia.149: 418-427.

GOMES, D.S., ALMEIDA, F.S., VARGAS, A.B. \& QUEIROZ, J.M. 2013. Resposta da assembleia de formigas na interface solo-serapilheira a um gradiente de alteração ambiental. Iheringia, Sér. Zool. 103: 104-109.

HÖLLDOBLER, B. \& WILSON, E.O. 1990. The ants. Cambridge: Belknap Press.

KASPARI, M., PICKERING, J., LONGINO, J.T. \& WINDSOR, D. 2001a. The phenology of a neotropical ant assemblage: evidence for continuous and overlapping reproduction. Behav. Ecol. Sociobiol. 50: 382-390.

KASPARI, M., PICKERING, J. \& WINDSOR, D. 2001b. The reproductive flight phenology of a neotropical ant assemblage. Ecol. Entomol. 26: 245-257.

NASCIMENTO, I.C., DELABIE, J.H.C. \& DELLA LUCIA, T.M.C. 2001. Phenology of mating flight in Ecitoninae (Hymenoptera: Formicidae) in a brazilian atlantic forest location. Ann. Soc. Entomol. Fr. 47: 112-118.

NAKANO, M.A., FEITOSA, R.M., MORAES, C.O., ADRIANO, L.D.C., HENGLES, E.P., LONGUI, L.E. \& MORINI, M.S.C. 2012. Assembly of Myrmelachista Roger (Formicidae: Formicinae) in twigs fallen on the leaf litter of Brazilian Atlantic Forest. J. Nat. Hist. 46: 2103-2115.

NENE, W.A., RWEGASIRA, G.M., NIELSEN, M.G. \& MWATAWALA, M. 2016. Nuptial flights behavior of the African weaver ant, Oecophylla longinoda Latreille (Hymenoptera: Formicidae) and weather factors triggering flights. Insectes Soc. 63: 243-248.

NIELSEN, M.G., PENG, R.K., OFFENBERG, J. \& BIRKMOSE, D. 2016. Mating strategy of Oecophylla smaragdina (Hymenoptera: Formicidae) in northern Australia. Austral. Entomol. 55: 261-267.

NOORDIJK, J., MORSSINKHOF, R., BOER, P., SCHAFFERS, A.P., HEIJERMAN, T. \& SYKORA, K.V. 2008. How ants find each other; temporal and spatial patterns in nuptial flights. Insectes Soc. 55: 266-273.

PEETERS, C. \& MOLET, M. 2010. Colonial reproduction and life histories. In Ant ecology (L. Lach, C.L. Parr, \& K.L. Abbott, ed.). Oxford University Press, Oxford, p.159-176. 
SANTOS, J.C. \& DEL-CLARO, K. 2009. Ecology and behaviour of the weaver ant Camponotus (Myrmobrachys) senex. J. Nat. Hist. 43: 1423-1435.

SOUZA, D.R., FERNANDES, T.T., NASCIMENTO, J.R.O., SUGUITURU, S.S. \& MORINI, M.S.C. 2012. Characterization of ant communities (Hymenoptera: Formicidae) in twigs in the leaf litter of the atlantic rainforest and eucalyptus trees in the southeast region of Brazil. Psyche J. Entomol. 2012: 1-12.

SOUZA-CAMPANA, D.R., SILVA, R.R., FERNANDES, T.T., SILVA, O.G.M., SAAD, L.P. \& MORINI, M.S.C. 2017. Twigs in the leaf litter as ant habitats in different vegetation habitats in Southeastern Brazil. Trop. Conserv. Sci. 10: $1-12$.
SUGUITURU, S.S., MORINI, M.S.C., FEITOSA, R.M. \& SILVA, R.R. 2015. Formigas do Alto Tietê. Canal 6, Bauru.

TORRES, J.A., SNELLING, R.R. \& CANALS, M. 2001.Seasonal and nocturnal periodicities in ant nuptial flights in the tropics (Hymenoptera: Formicidae). Sociobiology. 37: 601-626.

WILSON, E.O. \& HÖLLDOBLER, B. 2005. Eusociality: origin and consequences. Proc. Natl. Acad. Sci. U.S.A. 102:13367-13371.

YANOVIAK, S.P. \& KASPARI, M. 2000. Community structure and the habitat templet: ants in the tropical forest canopy and litter. Oikos. 89: 259-266.

Received: $19 / 11 / 2018$

Revised: 01/04/2019

Accepted: 11/04/2019

Published online: 09/05/2019 